\title{
MENGENAL MODEL PAUD BEYOND CENTRE AND CIRCLE TIME (BCCT) UNTUK PEMBELAJARAN ANAK USIA DINI
}

\author{
Aida Nur Fitri ${ }^{1}$, Christine Steffani Hutasoit ${ }^{1}$, Salsabila Afifah ${ }^{1}$ \\ ${ }^{1}$ PGPAUD, Kampus Daerah Cibiru, Universitas Pendidikan Indonesia, Jalan Raya Cibiru KM 15 \\ Bandung, Indonesia \\ Penulis untuk korespondensi/E-mail: aida.nf@upi.edu
}

\begin{abstract}
Abstrak - Artikel ini membahas mengenai model pembelajaran BCCT atau dikenal dengan model sentra yang memaparkan sejarah, kekurangan dan kelebihan, ciri utama, prinsip-prinsip, serta tujuan dari model BCCT/ Sentra ini. Artikel ini dibuat mengingat pentingnya model pembelajaran dalam pelaksanaan pendidikan anak usia dini, sehingga diharapkan dapat memperluas pengetahuan khususnya para pendidik sebagai pihak yang memiliki peran penting dalam penyelenggaraan pendidikan bagi anak usia dini. Penelitian ini menggunakan jenis penelitian kualitatif dengan merujuk pada penganalisisan deskriptif dari berbagai sumber yang relevan. Jenis studi yang digunakan yaitu studi kepustakaan dengan mengumpulkan informasi dari buku, jurnal, pembahasan artikel dan lainnya. Hasil penelitian ini diketahui bahwa model pembelajaran BCCT/ Sentra dapat mengarahkan anak untuk membangun pengetahuan mereka melalui sejumlah pengalaman yang didapatkan dari berbagai kegiatan bermain maupun lingkungan, ditambah lagi dalam implementasinya model ini tidak tergantung pada seberapa mahal alat dan bahan permainan, tetapi tergantung dengan seberapa kreatif dan inovatifnya pendidik tersebut merancang kegiatan belajar dan mengajar.
\end{abstract}

Kata kunci: Model Pembelajaran BCCT/ Sentra, Pendidikan Anak Usia Dini, Bermain

\section{Abstract}

This article discusses the BCCT learning model or known as the Sentra model that describes the history, shortcomings and advantages, main characteristics, principles, and objectives of this BCCT / Sentra model. This article was created considering the importance of learning models in the implementation of early childhood education, so that it is expected to expand knowledge, especially educators as parties who have an important role in the implementation of education for early childhood. This research uses this type of qualitative research by referring to descriptive analysis from a variety of relevant sources. The type of study used is literature study by collecting information from books, journals, article discussions and others. The results of this study found that the learning model that is suitable for use in early childhood education in Indonesia is the BCCT / Sentra learning model, because it does not require much equipment, but children's intelligence can still be optimized.

Keywords: BCCT/Center Learning Model, Early Childhood Education, Play

\section{PENDAHULUAN}

$\mathrm{P}$ endidikan merupakan salah satu hal yang penting untuk dicapai oleh seorang individu, karena sejatinya pendidikan adalah kebutuhan dasar bagi setiap kehidupan manusia. Sebagaimana telah ditetapkan dalam Undang-Undang Republik Indonesia tentang Sistem Pendidikan Nasional No 20 Tahun 2003 bahwa pendidikan adalah usaha sadar dan terencana untuk mewujudkan suasana belajar dan proses pembelajaran agar peserta didik secara aktif menggembangkan potensinya sehingga memiliki kekuatan spiritual keagamaan, pengendalian diri, kepribadian berakhlak mulia, memiliki pengetahuan yang baik, serta dapat terampil di lingkungan masyarakat hingga bangsa dan negara. Artinya, setiap individu memiliki hak dan kesempatan untuk mengembangkan seluruh potensi mereka melalui lembaga pendidikan yang tersedia di suatu bangsa dan negara sehingga individu 
tersebut dapat terampil dalam mengembangkan potensinya sesuai dengan kebutuhan di bidang masing-masing. Pendidikan juga dapat ditempuh oleh seluruh kalangan jenjang dan usia, termasuk pada anak usia dini. Pendidikan pada anak usia dini merupakan salah satu upaya pembinaan yang diberikan kepada anak berusia 0 hingga 6 tahun sebagai bentuk stimulasi pendidikan yang bertujuan untuk membantu mengembangkan seluruh aspek-aspek perkembangan dan pertumbuhan anak secara optimal serta menyiapkan anak ke jenjang pendidikan selanjutnya (Sudirjono, 2013).

Untuk mencapai keberhasilan pendidikan perlu melibatkan segala bentuk persiapan rangkaian belajar seperti teknik pembelajaran, metode pembelajaran, strategi pembelajaran, pendekatan pembelajaran, dan model pembelajaran. Hal ini perlu diterapkan dan dilaksanakan pada suatu lembaga pendidikan agar saat menyampaikan materi pembelajaran tetap mengacu pada teoriteori maupun landasan yang sesuai dengan pendidikan anak usia dini. Karakteristik belajar pada anak usia dini memiliki perbedaan dari jenjang pendidikan lainnya, dimana gaya belajar mereka harus disesuaikan dengan tingkat kebutuhan, usia serta prinsip belajar yang ada (Hijrati, 2017). Setelah mengetahui karakteristik belajar setiap anak, guru dapat menentukan rangkaian belajar yang tepat bagi anak didiknya tersebut.

Model pembelajaran juga tentunya sangat penting dalam melaksanakan pembelajaran agar dapat dicapai secara efektif dan efisien. Beragam jenis model pembelajaran dapat diterapkan di PAUD, seperti model Frobel, model Montessori, model sistem among, model Reggio Emilia, model High Scope, model BCCT/Sentra, dan masih banyak lagi. Namun, kunci utama pembelajaran anak usia dini terletak pada sistem pembelajaran yang didalamnya meliputi proses serta tujuan pelaksanaan pendidikan. Sistem pembelajaran tergantung pada model pembelajaran yang digunakan, salah satunya adalah model Beyond Centers and Circle Time (BCCT). Menurut Fitriah (2020), model pembelajaran yang menantang dan menyenangkan adalah model pembelajaran sentra karena melibatkan unsur bermain, bergerak, bernyanyi dan belajar.

Pembelajaran berbasis sentra merupakan pembelajaran yang cocok dilaksanakan di lingkungan pendidikan anak usia dini, dengan karakteristik utamanya memberikan pijakan (scaffolding) untuk membangun konsep aturan, ide dan pengetahuan anak (Saputri, 2019). Dalam kegiatannya, model pembelajaran ini berfokus pada anak sebagai subjek pembelajaran, berpusat di sentra bermain dan pada saat anak dalam lingkungan. Peran pendidik lebih banyak sebagai motivator dan fasilitator dengan memberi pijakan-pijakan. Pijakan yang diberikan sebelum dan sesudah anak bermain dilakukan dalam setting duduk melingkar sehingga dikenal dengan sebutan "saat lingkaran". Dalam model ini, anak dirangsang untuk aktif melakukan kegiatan bermain sambil belajar di sentra-sentra pembelajaran, dimulai dari mengembangkan ide hingga tuntas menyelesaikan hasil karyanya.

\section{METODE PENELITIAN}

Penelitian ini menggunakan jenis penelitian kualitatif dengan merujuk pada penganalisisan deskriptif dari berbagai sumber yang relevan. Jenis studi yang digunakan yaitu studi kepustakaan dengan mengumpulkan informasi dan data-data dari, buku, jurnal, pembahasan artikel dan lainnya. Metode dalam penulisan yaitu menggunakan metode analisis isi dari berbagai sumber yang terpercaya yang sesuai dengan tema atau bahasan yang telah ditetapkan, lalu menyimpulkannya. Tahapan dalam melakukan penelitian ini yang pertama menentukan tema atau bahasan yang akan dibahas, kemudian mencari dan mengumpulkan sumber-sumber yang relevan, selanjutnya mengkaji dan menganalisis berbagai materi dari sumber yang sudah ditemukan, memilih referensi yang akan digunakan, lalu yang terakhir dituangkan ke dalam artikel ini (Mizaqon \& Purwoko, 2018).

\section{HASIL DAN PEMBAHASAN}

\section{A. Sejarah Model Pembelajaran Sentra}

Model pembelajaran sentra adalah sebuah model pembelajaran yang menjadikan bermain di sentra sebagai wahana belajar anak. Pendekatan ini lebih menekankan pada aktivitas eksplorasi lingkungan, anak-anak belajar di sentra yang dilengkapi dengan sejumlah alat permainan dengan tujuan agar berfungsi sebagai pijakan (Scaffolding). Pijakan-pijakan yang disediakan digunakan 
untuk dapat mendukung berbagai aspek perkembangan anak, yaitu Moral-Agama, FisikMotorik, Bahasa, Kognitif, Sosial-Emosional dan Seni (Saputri, 2019).

Model pembelajaran sentra ini dikembangkan oleh Creative Curriculum, pengelola kegiatan pembelajaran yang seimbang antara bimbingan guru dengan inisiatif anak. Konsep pembelajaran sentra ditemukan berdasarkan hasil teoritik dan pengalaman Dr. Pamela Phelps selama 40 tahun mengabdi di CCCRT Florida, yaitu sebuah lembaga penyedia pelatihan dan penelitian tentang perkembangan anak di Amerika Serikat. Departemen Pendidikan Nasional Republik Indonesia secara resmi mengadopsi pembelajaran sentra pada tahun 2004 (Fitriah, 2020).

Saputri dalam artikelnya menyatakan bahwa di Indonesia, pembelajaran sentra pertama kali diadaptasi oleh lembaga PAUD berlatar belakang Islam, adalah Nibras binti OR Salim, pimpinan TK Istiqlal Jakarta, yang pernah terbang langsung ke CCCRT melakukan riset selama tiga bulan ke Florida (Saputri, 2019). Pembelajaran sentra dianggap paling ideal diterapkan di Indonesia, selain tidak memerlukan peralatan banyak, kecerdasan anak tetap bisa dioptimalkan. Pembelajaran sentra diyakini mampu merangsang seluruh aspek kecerdasan anak (Multiple Intelegent) melalui bermain yang terarah. Semenjak model pembelajaran pembelajaran sentra ini diterapkan di Indonesia, terdapat 7 kegiatan bermain melalui sentra yaitu, sentra bahan alam, sentra seni, sentra balok, sentra persiapan, sentra imtaq, sentra main peran besar, dan sentra main peran kecil.

\section{B. Tujuan Dilaksanakannya Pembelajaran Berbasis Sentra}

Model pembelajaran sentra merupakan model pembelajaran yang berfokus pada anak, yang penerapannya berpusat pada sentra bermain dan saat anak dalam lingkaran dengan memperhatikan dukungan kepuasan belajar, bermain, dan suasana emosi anak (Anggraini, 2020). Tujuan dilaksanakannya pembelajaran berbasis Sentra adalah 1). Pengoptimalan terhadap potensi kecerdasan jamak: yang mana dapat memecahkan masalah hingga dapat menciptakan produk yang bernilai; 2) Penanaman nilai-nilai dasar, yang mana anak dikenalkan dan diproses dengan pemahaman mengenai sopan santun dan tata krama yang baik meliputi, nilai-nilai agama, nilai- nilai sosial, nilai-nilai moral, dan nilai-nilai etika; serta 3) Pengembangan kemampuan dasar. Artinya, inti pokok dari tujuan model pembelajaran sentra ini yaitu untuk menstimulasi berbagai aspek perkembangan anak usia dini melalui kegiatan bermain yang disusun menggunakan berbagai pijakan dan memberi keleluasan untuk anak usia dini dalam memperoleh pengalaman yang mana nantinya akan menjadi sumber pengetahuan dan informasi serta pembentukan karakter anak.

\section{Prinsip Pelaksanaan Model Pembelajaran Sentra}

Prinsip-prinsip dalam penyelenggaraan model pembelajaran sentra adalah sebagai berikut (Martuti, 2009):

1. Keseluruhan proses pembelajaran berdasarkan teori dan pengalaman empiris

2. Setiap proses pembelajaran wajib agar merangsang semua aspek kecerdasan anak melalui permainan yang terarah dan dukungan pendidik pada 4 jenis pijakan.

3. Menempatkan penataan lingkungan main menjadi pijakan awal yang merangsang anak agar aktif, kreatif dan terus berfikir menggunakan pengalaman yang sudah dilalui.

4. Menggunakan standar operasional pada buku proses pembelajaran

5. Mensyaratkan pendidik dan pengelola agar mengikuti pembinaan atau pelatihan sebelum menerapkan metode ini.

6. Melibatkan orang tua atau pengganti orang tua menjadi satu kesatuan proses pembelajaran agar mendukung aktivitas yang dilakukan oleh anak ketika di rumah.

Setiap anak dapat memilih pusat pembelajaran mana yang akan digunakan untuk belajar dan bermain. Media dan lingkungan bermain yang digunakan di setiap sentra harus aman, nyaman dan menarik bagi anak, dan waktu yang tersedia akan disesuaikan dengan kebutuhan anak sehingga mereka dapat belajar dengan nyaman saat belajar. Prinsip-prinsip dalam pembelajaran sentra ini terpusat umumnya mewakili kebutuhan pembelajaran untuk perkembangan anak yang optimal. Kegiatan belajar yang berpusat pada anak 
dibangun atas dasar bahwa anak-anak yang berbeda memiliki metode belajar, gaya belajar, dan minat yang berbeda dalam pengetahuan yang ingin dimilikinya. Pernyataan ini sesuai dengan pendapat Day dalam Sujiono (2010) yang mengatakan bahwa pusat kegiatan belajar dapat mengatasi perbedaan dari gaya belajar, tingkat kematangan, dan perkembangan anak, serta perbedaan dari latar belakang.

\section{Ciri Utama Model Pembelajaran Sentra}

Model pembelajaran sentra memiliki ciri utama memberikan scaffolding untuk membangun bersama berdasarkan konsep, aturan, ide dan pengetahuan anak. Ini juga didukung dalam kurikulum Standard Florida dan Sunshine BCCT. Fokus model pembelajaran sentra ini adalah pada playcentre, dimana anak-anak berada dalam lingkaran. Pijakan disini maksudnya berupa bentuk dukungan untuk perkembangan anak yakni, pijakan lingkungan bermain, pijakan sebelum anak bermain, pijakan perseorangan selama anak bermain, dan pijakan setelah anak bermain. Untuk membantu mengoptimalkan pijakan tersebut, pembelajaran sentra menerapkan konsep densitas dan intensitas bermain. Konsep densitas menekankan pada bentuk kegiatan seperti apa yang dirancang oleh seorang pendidik di lingkungan anak usia dini. Sedangkan, pada konsep intensitas bermain menekankan pada alokasi waktu yang dibutuhkan anak untuk berpindah bermain melalui lima tahap perkembangan selanjutnya (Rismawati, 2009). Berpijak pada ciri pemberian scaffolding serta penerapan densitas dan intensitas diyakini akan membantu keberhasilan anak dalam menempuh pendidikan.

Di samping itu, model pembelajaran sentra ini sangat mengutamakan perasaan puas anak ketika sedang melakukan pembelajaran, bermain, bereksplorasi dan menyalurkan minatnya (Sujiono, 2013, p. 217). Ciri-ciri lain yang harus diperhatikan dalam penggunaan model pembelajaran sentra, yaitu: 1). Pembelajaran berpusat pada anak; 2). Jadikan lingkungan game sebagai titik awal yang penting; 3). Sebagai pendidik, kita harus membantu semua anak belajar menjadi positif dan kreatif serta membuat keputusan sendiri; 4). Peran pendidik sebagai moderator, motivator dan evaluator; 5). Aktivitas bermain di Playcentre menjadi fokus minat anak; 6). Adanya standar operasional prosedur (SOP) (baik di pusat maupun di daerah); dan 7). Anak-anak diatur sebelum dan sesudah bermain dalam lingkaran.

\section{E. Kelebihan dan Kekurangan Model Pembelajaran Sentra}

Tidak ada satupun model pembelajaran yang sempurna, termasuk model pembelajaran sentra. Hijriati (2017) mengemukakannya sebagai berikut:

\section{Kelebihan}

Kelebihan yang dimiliki yaitu mampu memberikan pengalaman bermain secara lebih lengkap dan mendalam melalui pembagian sentra-sentra dalam lingkaran. Selain itu, kelebihan lainnya bahwa model ini lebih fleksibel dan kontekstual, sehingga sesuai dengan Kurikulum Tingkat Satuan Pendidikan (KTSP).

\section{Kelemahan}

Kelemahan model pembelajaran pembelajaran sentra ini, yaitu penekanan pada sentra dapat menghalangi serta menghambat anak untuk bereksplorasi dalam memilih permainan yang mereka inginkan. Model ini juga menjadikan anak tidak dapat berpindah kepada kegiatan lain sebelum menuntaskan permainan yang disajikan oleh guru. Sehingga model ini dapat disebut memberikan pengalaman bermain yang mendalam, tetapi sempit.

Kelemahan lain dari model pembelajaran sentra yaitu karena dalam kegiatan pembelajarannya memerlukan berbagai macam sentra, maka guru harus mempersiapkannya. Salah satu sentranya yaitu sentra membaca dan menulis. Dari hasil penelitian yang dilakukan oleh Siron (2019) mengenai kendala guru PAUD mengembangkan sentra membaca dan menulis, didapat kesimpulan bahwa masih terdapat banyak kendala dalam mengembangkan sentra membaca dan menulis diakibatkan berbagai faktor seperti media pendukung, keadaan peserta didik, dari guru itu sendiri, dan sebagainya.

Sementara menurut Wahyuningsih (2020), kelebihan model pembelajaran sentra ini, yaitu: 1). Anak didorong untuk bermain di sentra-sentra kegiatan yang dapat 
meningkatkan kemandirian dan kepercayaan diri, sedangkan pendidik berperan sebagai fasilitator yang merencanakan, mendukung, menilai kegiatan anak, serta memberikan dukungan, sehingga anak menjadi aktif, kreatif, dan berani mengambil keputusan sendiri tanpa takut membuat kesalahan; 2). Pembelajaran yang bersifat individual menjadikan rancangan dukungan dan penilaian yang dilakukan akan disesuaikan dengan tingkatan perkembangan kebutuhan setiap individu anak; 3). Semua tahap perkembangan anak dirumuskan dengan rinci dan jelas yang sebelumnya telah disiapkan oleh guru, sehingga guru memiliki panduan dalam penilaian terhadap perkembangan anak; 4). Kegiatan pembelajaran pada model BCCT ini tertata dalam urutan yang jelas, mulai dari penataan lingkungan main sampai pada pemberian pijakan-pijakan; dan 5). Model BCCT dilaksanakan secara bertahap sesuai dengan situasi dan kondisi sehingga dalam pelaksanaannya tidak bersifat kaku.

Adapun kekurangannya adalah: 1). Membutuhkan waktu yang lebih banyak bagi pendidik untuk membuat perangkat pembelajaran lengkap sesuai capaian perkembangan setiap anak dan memerlukan biaya untuk membuat media bermain, kecuali pendidik pendidik memanfaatkan barang daur ulang untuk membuat media bermain; 2). Banyak pendidik yang belum memahami sintak dalam pendekatan BCCT; dan 3). Kurangnya koordinasi antara pendidik dan orang tua sehingga seringkali apa yang sudah dilakukan oleh anak di sekolah tidak ditindaklanjuti oleh orang tua di rumah; dan Manajemen pengaturan waktu yang yang sering terlewatkan karena kontrol dari pendidik yang kurang.

\section{F. Alat dan dan Bahan}

Sebelum kegiatan pembelajaran dimulai seorang guru hendaknya mempersiapkan media-media pembelajaran yang menunjang keberhasilan anak sebagaimana dalam menempuh pendidikannya. Proses pembelajaran bagi anak usia dini dapat dipandang sebagai wahana bermain yang tampak menyenangkan, mengasyikan dan membawa suasana gembira. Wahana bermain yang dirancang dapat didukung dengan alat dan bahan dapat mengoptimalkan ruang gerak anak dalam mengeksplorasi dunianya lebih lagi karena sejatinya dunia anak adalah bermain dan lingkungan merupakan tempat yang tepat untuk anak dapat memperoleh berbagai hal dalam membangun pengalaman, pengetahuan, kreativitas dan kerjasama.

Penerapan pembelajaran dapat dibantu dengan media yakni alat, bahan serta benda-benda sederhana (Aryanti, 2013). Hal ini dapat ditemukan pada lingkungan alam sekitar sebagaimana yang biasanya ditemukan oleh anak-anak di dalam kehidupan sehari-harinya seperti pasir, botol plastik, biji-bijian, sedotan dan sebagainya. Selain media benda sederhana dan mudah ditemukan, alat dan bahannya pun tidak mengeluarkan harga yang mahal. Sehingga dapat meningkatkan minat anak dalam belajar dan mengembangkan potensi anak dengan cara pemberian stimulus secara optimal.

Penggunaan pembelajaran sentra dapat menempatkan anak pada posisi yang proporsional. anak dirangsang dengan bermain sambil belajar. Menurut Romini (Romini, 2021), terdapat beberapa sentra yang dapat dikenakan pada anak dimana anak dapat belajar dan bermain, seperti:

1. Sentra Persiapan, yang diperuntukan untuk mempersiapkan kematangan kemampuan dasar anak sehingga siap untuk memasuki sekolah dasar. Perlengkapan main yang disediakan dalam sentra persiapan, yaitu manik-manik, puzzle, timbangan, kartu huruf, alat tulis, gunting, alat menggambar dan alat lainnya yang dapat mendukung kemampuan klasifikasi, keaksaraan, dan motorik halus anak.

2. Sentra Balok, yang diperuntukan untuk mengembangkan kemampuan berpikir dengan media pembangunan terstruktur. Perlengkapan main yang disediakan dalam sentra balok, yaitu balok berbagai ukuran dan bentuk, aksesoris seperti bonekaboneka, alas balok, yang semuanya tersedia dalam berbagai warna.

3. Sentra Peran, terdiri dari peran besar dan peran kecil. Sentra peran besar memberikan kesempatan kepada anak untuk mengembangkan pengetahuan tentang dunia sekitarnya dengan cara bermain pura-pura mengikuti peran seseorang seperti dokter, ibu, ayah, binatang dan sebagainya. Sedangkan sentra peran kecil memberikan kesempatan kepada anak untuk bermain simbolik, bermain pura-pura dengan menggunakan 
benda-benda kecil dan menggerak-gerakannya. Perlengkapan main yang disediakan dalam sentra peran, yaitu berbagai alat rumah tangga, alat berbagai profesi, benda-benda berukuran mini, dan alat-alat lain yang mendukung anak untuk bermain peran.

\section{SIMPULAN DAN SARAN}

Adapun simpulan dari paparan mengenai model pembelajaran sentra ini adalah bahwa model pembelajaran sentra mengarahkan anak untuk membangun pengetahuan mereka melalui sejumlah pengalaman yang didapatkan dari berbagai kegiatan bermain maupun lingkungan. Anak didorong untuk bermain di setiap sentrasentra yang dirancang, sedangkan pendidik berperan sebagai perancang, pendukung serta fasilitator bagi anak dengan mengacu pada prinsip-prinsip, langkah-langkah serta tahapan belajar model pembelajaran sentra.

Implementasi model ini tidak tergantung pada seberapa mahal alat dan bahan permainan, tetapi tergantung dengan seberapa kreatif dan inovatifnya pendidik tersebut merancang kegiatan belajar dan bermain terlaksana. Banyak hal yang dapat pendidik gunakan agar menjadi media pembelajaran yang mendukung proses pembelajaran salah satunya dengan memanfaatkan bahan-bahan alam ataupun lingkungan sekitar yang mampu mengembangkan seluruh aspek perkembangan anak usia dini.

Sehubungan dengan simpulan yang telah dipaparkan, terdapat saran dalam pelaksanaan pembelajaran sentra seperti, sebagai fasilitator guru harus dapat memfasilitasi penciptaan informasi baru, memberikan siswa kesempatan untuk menemukan dan menerapkan ide-ide mereka, dan membuat mereka peka terhadap jalan mereka sendiri, maka dari itu guru di semua sekolah juga harus dapat mengidentifikasi nilai yang ditanamkan pada anak-anaknya melalui kegiatan bermain. Dengan begitu, aktivitas bermain lebih dari sekedar aktivitas fisik, bukan hanya sebagai sarana pembentukan perilaku anak saja.

\section{DAFTAR PUSTAKA}

Anggraini, E. S. (2020). Penanaman nilai karakter anak usia dini pada model pembelajaran BCCT (beyond centers and circle time) di TK Pembina Sukaramai, Kecamatan
Kerajaan, Kabupaten Pakpak Baharat. Jurnal Usia Dini, 6(2), 20-27.

Aryanti, N. M. W., Suarni, N. K., \& Ambara, D. P. (2013). Penerapan model pembelajaran BCCT (beyond center and circle time) berbantuan media benda sederhana untuk meningkatkan perkembangan kognitif pada anak. Jurnal Pendidikan Anak Usia Dini Undiksha, 1(1).

Fitriah, W. (2020). Implementasi model bcct (beyond center and circle time dalam pendidikan anak usia dini di paud dori way kanan (Doctoral dissertation, UIN Raden Intan Lampung).

Hijriati, H. (2017). Pengembangan model pembelajaran pendidikan anak usia dini. Bunayya: Jurnal Pendidikan Anak, 3(1), 74-92.

Martuti, A. (2009). Mendirikan dan Mengelola PAUD Manajemen Administrasi Strategi Pembelajaran. Yogyakarta: Kreasi Wacana.

Mirzaqon, A., \& Purwoko, B. (2018). Studi Kepustakaan Mengenai Landasan Teori dan Praktik Konseling Expressive Writing. Jurnal BK Unesa, 8(1), 1-8.

Romini, R. (2021). Implementasi Model Pembelajaran Beyond Center and Circle Time (BCCT) Sebagai Upaya Meningkatkan Kualitas Pendidikan. EDULEAD: Journal of Christian and Leadership, 2(2), 219-234.

Rusmawati, N. (2009). Pelaksanaan pembelajaran pendekatan Beyond Centers and Circle Time (BCCT) di Pusat Paud Firdaus International Preschool Banjarnegara (Doctoral dissertation. UNS (Sebelas Maret University).

Saputri, E. E. (2019). Implementasi model pembelajaran sentra untuk meningkatkan kemandirian anak usia dini di KB Merak Ponorogo. (Doctoral dissertation, IAIN Ponorogo).

Siron, Y. (2019). Kendala guru paud mengembangkan sentra membaca dan menulis (studi kasus di Jakarta Timur 2018). Cakrawala Dini: Jurnal Pendidikan Anak Usia Dini, 10(2), 142150.

Sujiono, Y.N. Sujiono, B. (2010). Bermain kreatif berbasis kecerdasan jamak di sertai langkah pengembangan program kegiatan bermain di kelompok bermain, 
Fitri, Hutasoit, Afifah., Vol. 4 No. 2, pp. $72-78$

taman kanak-kanak, dan pos PAUD. Jakarta: INDEKS.

Sujiono, Y.N. (2013). Konsep Dasar Pendidikan Anak Usia Dini. Jakarta: PT. Indeks.
Wahyuningsih, D. (2020). Model pembelajaran bect bagi anak usia dini sesuai dengan tahap perkembangan. Dunia anak: Jurnal Pendidikan Anak Usia Dini, 3(1), 58-69. 